\title{
Women's Political Participation in Indonesia's Reform Era: Local Government Perspective
}

\author{
Mudiyati Rahmatunnisa \\ Department of Political Science, Faculty of Social \& \\ Political Science, Padjadjaran University \\ Bandung, Indonesia \\ m.rahmatunnisa@unpad.ac.id
}

\begin{abstract}
Women's political participation is defined as the actual and equal involvement in the implementation of various government activities, whether through election or appointment. Various studies have shown that the quantity and quality of active involvement of women in public life is essential. The study aimed for increase in women's participation has been correlated with economic growth, cohesion and sustainable conflict resolution. Having said that, the phenomenon in Indonesia shows that women's political participation is still considered low amidst the nation's transition towards democracy era. How this problem can be explained? This study will specifically discuss a variety of phenomena related to women's political participation and its problems and challenges. Instead of using national perspective, this paper will use local perspective in order to gain different information and results.
\end{abstract}

Keywords—: political participation, gender, affirmative action

\section{INTRODUCTION}

Within democratic societies, the quantity and quality of active involvement of women in public life is essential. Long ago, in the UN Convention on the Elimination of all Forms of Discrimination against Women (CEDAW) 1979, it was clearly stated that maximum participation of women on equal terms with men in all fields was the requisite for achieving the full and complete development, the welfare of the society and peaceful living [1]). Other study also showed that the increase in women's participation has been associated with economic growth, cohesion and sustainable conflict resolution [2]. Many countries in the world have ratified the Convention and adopted various policies in order to strengthen women's political participation, including Indonesia.

Nevertheless, recent studies reveal that women's political activities have still been marginal or non-existent, not only in Third World countries, but Western countries as well [3]. Indonesia is not an exception in case. Although a number of conventions have been ratified by the Indonesian government since 1968

Including the UN Convention on Political Rights for Women, the UN Convention of the Elimination of all Forms of Discrimination against Women (CEDAW), the Optional Protocol of the Women's Convention, and the Beijing Platform, it was reported that Indonesian women have still been marginalized from the power structure and decision making process. It was not until the demise of Suharto's

\author{
Dede Mariana \\ Department of Political Science, Faculty of Social \& \\ Political Science, Padjadjaran University \\ Bandung, Indonesia
}

authoritarian regime in mid-1998 that Indonesian women have granted wider opportunity to be active in public sphere. Pioneered by a number of active and outspoken civil society organizations and women activists, in early 2000 Indonesia entered a new phase in terms of strengthening women's political participation. The country's political agenda was colored by heightened debate regarding the importance of strengthening women's political representation and participation in political activities. The debates particularly focused on how to increase the number of women holding positions in political institutions. Such debates on gender and democracy were triggered by three factors: first, the long history and continuous underrepresentation of Indonesia women in all levels of decision-making. Second, Indonesia's transition to democracy has opened up the opportunities for women to articulate their demands for greater gender awareness and sensitivity in various government policies. And third, triggered by the economic crisis in 1997 wherein women were the most sufferers, demands for more women's representation increased in all levels and in all aspects of political life [4].

One of the important milestones of those intensive struggles led by the activists was the adoption of affirmative action policy within the 2002 Political Party Law and the 2003 Electoral Law which then strengthened within the Law 2008 Electoral Law. The policy basically obliged the participating political parties to include at least 30 per cent $(30 \%)$ of women in their respective legislator candidate list. Similar percentage was also imposed for political party's board [5]. Such an achievement marked an era of Indonesian government's serious effort in bringing gender equality into reality. Needless to say, such a policy has the potential in improving not only women's political representation in legislative body both at national as well as local level, but also it could become a corner stone for more women's political activities in various public spheres.

Couple of years before the stipulation of those laws, there was the Presidential Decree (IPRES) No. 9/2000 on Gender mainstreaming in National Development Planning and Programming which was considered as a step towards making governance gender responsive. Later on, commitment to gender equality was reaffirmed within Law No. 17/2007 on the National-long term Development Plan (RPJPN) 2005-2025. As the instrument of the said law, the Ministry of Home Affairs (MoHA) has issued Circular Letter in 2008 on Provincial Government Annual Work plan Development, mandating all 
provinces to use gender analysis in the planning and budgeting process. In addition, the Budget Statement of 2009 mandates all government agencies in Indonesia to implement a performance budgeting system, with gender-based perspective. In a nutshell, Indonesia policy context is relatively supportive of gender equality.

Yet, whether it really has substantial impact on bringing more women involve in political arena and further impact on political agenda which reflects gender-related issues becomes an interesting question to be discussed. In her essay, Budianta [6] for example, firmly asserts that although gender mainstreaming has been a familiar catchword in the public discourse, statistics show that women's participation in state formal politics remains small. Obviously, Budianta further argues that "organizational machinery reforms" have rested on gender-neutral assumptions live in societies wherein women are invisible. Hence, gender-related issues such as domestic violence, family welfare, affordable education and infant malnutrition are mostly sidelined. How can this be explained?

Having explained the above, discussing Indonesia women's political participation in the aftermath of Suharto's fall becomes interesting, particularly in terms of investigating the effectiveness of various regulations designed to strengthened it. Needless to say, studies on this subject have been conducted by many scholars. These studies were mainly oriented around national perspective. Where research is still most limited however is from the perspective of specific local government. Using local government perspective, this paper attempts to fill part of the void by discussing women's political participation trough a case study in City of Cirebon, West Java, in order to gain different insight and more specific information.

The paper will be divided into four sections. After this introduction section, it will be followed by section discussing briefly about research method. The next section will focus on discussing the main results so this study on women's political participation in City and District of Cirebon. The paper will be ended by brief concluding remark

\section{METHOD}

This study employs qualitative research method through a case study which involves a variety of elements designed so as to gather comprehensive information and data about the issue in question. In addition, the study also utilizes a theory-driven approach by using several established theories as the basis for understanding and investigating the selected topic. The information and data are gathered from primary and secondary resources through interviews with a number of key informants as well as documentary technique by examining various documents such as local government's reports, web pages, and newspapers both national and local. In addition, this study also relies heavily on other secondary materials such as journal articles, books, papers and research reports.

The data are analyzed qualitatively which basically carried out simultaneously with data gathering activities and writing up of findings. The data are reviewed and organized into categories or themes that cut across all the data sources. The data are validated through triangulation strategy. It is conducted by "examining evidence from sources and using it to build coherent justifications for the themes."

\section{RESULT AND DISCUSSION}

Political participations matters a great deal not only for men, but also for women. The importance of women's political participation or representation is rooted in both intrinsic as well as instrumentalist argument. Using human rights perspective, the former emphasizes that since women constitute more than half of the world population, therefore they deserve equal participation and representation. While the latter points out that women's political participation is essential because men and women are indeed different in both vision and concepts of politics owning to their sex and gender roles. Hence, it is assumed that women's inclusion in politics would bring different focus and values to politics. By the same token, Dahlerup [7] argues that women have the right to half the seats since they constitute half of the population (the justice argument). Then, women's representation is a must because they have different experiences biologically or socially (the experience argument). In addition, men and women have to be represented by themselves since they have conflicting interests (the interest group argument). The significance of women's political participation and representation is one of the fundamental prerequisites for a truly vibrant democratic society, together with the institutionalization of the rule of law and democratic procedures. A number of studies also have associated women political participation with economic growth and poverty. Xu's study [8] on 30 countries in Asia during the period 1991-2013 for example, shows that women's political participation has fostered economic growth in Asia.

Although the above explanation reveals the importance of women political participation, for many countries around the world it remains low, with only a few cases that could be considered substantially successful. Cirebon represents an interesting case in discussing women's political participation. As a number of studies confirmed that amidst high expectation of Indonesian women's role in politics, they still lag behind their male counterparts in various aspects of public affairs. Cirebon is not an exception in this matter. In terms of women representation in respective local assemblies - District as well as City of Cirebon - they have been among the lowest in Indonesia. The discussion is even more strategic and interesting because Cirebon is notable for its strong Islamic tradition which presumably has strong influence on people's political attitude and preferences. As we all might know, Islam is among determinant factors of women marginalization in politics.

Although we cannot simplify the concept of political participation into only political representation in legislative body, one intriguing figure that attracts our attention from Cirebon is the small percentage of female representatives in both Local Assemblies (DPRD) of City and District of Cirebon. In the DPRD of City of Cirebon in particular, female legislators occupied 6.7 per cent ( 2 female members from total of 30) since the era of so-called Reformasi. In fact, at the end of Suharto's authoritarian regime (1997-1999), members of DPRD were all male. Underrepresentation also occurs in the DPRD of District of Cirebon, although with a slightly higher 
percentage. During 2004-2009, there were only five (10 per cent) female members from the total of fifty. As a result of 2009 election, there was a slight increase of female legislators from only five to seven (14 per cent) from total of fifty.

Both cases show that affirmative action policy in the form of gender quota could not increase the number of female representatives. A series of interviews reveals interesting phenomena. Following Norris and Lovenduski [9] factors that contribute to the low percentage of women in both legislative bodies can be divided into two interrelated factors: "supply" and "demand" factors. A series of interview shows that the low percentage of Cirebonese women in political activities before and after the enforcement of affirmative action policy is due to lack of interests to be active in politics. Most of the informants perceive that political arena belongs to male. It isparticuarly rooted in the dominance thought among Cirebonese women that politics is a tough, challenging and dirty game wherein women do not fit in it. Obviously, this kind of thought has significantly reduced women's confident in their ability to be active in political activities such as being member of local assembly.

Lack of confidence to be involved in politics is also rooted in the lack of competency and experience in managing public affairs as well as low level of education. Another interesting reason is related to what scholars have called - dual burden. It is believed that female legislators will have limited commitment in fulfiling their duties because they still have full responsibilities in their respective households - as mothers and wives. They in fact have very strong thought that becoming members of local assembly will certainly reduce their time with their children and husbands. This is something that most Cirebonese women are eager to avoid.

Women's reluctance has also been voiced by members of political parties' boards. They admit that they faced difficulties in recruiting women candidates whereas it is compulsory for them as stipulated within the General Election Law. As a result, political parties' boards recruited women candidates without applying objective and ideal standards.

From "demand" factors, low percentage of women particularly comes from political parties' ignorance and strong resistance from male counterparts due to political rivalries. This is particularly true before the adoption of affirmative action policy. Following the adoption of the policy within the 2008 Electoral Law, such parties'igorance and male counterparts' resistance have slighty reduced. Political parties are obliged to include at least 30 per cent women in its candidate list.

It is also admitted that the struggle of Cirebonese women candidates has not stop at the formulation of candidate list. It actually continues during the election process. Women candidates obtained less support from their party compared to their male counterparts, especially in terms of financial support and access to political networks. These limitations provide significant barrier particularly during campaign phase. No less shocking barrier is resistence from Cirebonese women themlesves. It was admiited by the elected female legislator, strong resistance in fact come from women constituents just because her status as a widow, divorcee, and a beautician - a status that is "socially" underestimated and stereotyped. Often, during campaign period, she received threats from groups of women, asking her to resign from her candidacy. What is more interesting in this particular case, the elected female legislator in fact gained most votes from male constituents. She actually won by a landslide in her religious and traditional electoral district, defeating her male competitor who actually won by a landslide in most of the electoral districs. It is interesting to note here that she won not because of her pltaforms better than her competitors, but because of rather bizarre reasons, namely she is the daughter of an influential local Kyai (Islamic cleric) and she is beautiful.

Research also reveals that dual burden has also limited female candidates to have optimum election campaigns. Often, female candidates refuse to conduct campaign just because it has passed normal working hours. They have to be at home by that time. Whereas their male counterparts have much more freedom and time to go anywhere and anytime they like without fear of abandoning household responsibilities. In turn, this situation could reduce female candidates' chances to be elected.

By referring to a survey conducted by Prosperous Justice Party (PKS), no less interesting finding shows that actually local constituents do not bother whether their representatives would be male or female. It is worth emphasizing here that the reason is nothing to do with religion as one might expect. Rather, it is tended to be pragmatic when it comes to vote, meaning that they will give their votes to those who can give "tangible benefits" regardless their gender, such as money, infrastructures or the like. This also implies that balanced representation between male and female legislators and the importance of gender sensitive decision-making process are not in their radar.

Simply put, Cirebonese women face significant barriers internal and external - to run for election. Political, cultural and socio-economic factors are found to be unfriendly or hostile to their candidacies. Thus, it seems plausible that the number of female legislators have always been small compared to their male counterparts.

Obviously, challenges and hardship faced by female legislators do not fade out, let alone vanish. It is admitted that female legislatures find themselves difficult to perform as expected. In fact, their performances tend to be inferior and less popular compared to their male counterparts. One ultimate reason for that is because they are outnumbered and so too their opinions and initiatives. Simply put, numbers matter.

Another irritating reason is with regard to political party's policies. It is admitted that often, their obligation to follow party's policies should be their ultimate priority than representing specific and limited women's interests and needs that might not the party's primary concerns. There are firmed sanctions for those who disobey party's policies. As a consequence, as highlighted by male legislators, so far the existence of female legislators have not significantly contributed to decision-making process or brought gendersensitive issues whatsoever. 
It is also widely admitted that low performance of female legislators and their weaker bargaining position vis-à-vis their male counterparts is also rooted in their limited capabilities and lack of experience in political debate settings. Interesting comment actually comes from male legislators that their "junior" female colleagues are not as good as their "senior" female colleagues. It is obvious that long period of political education and training in political arena has made senior female legislators better than junior ones.

In a nutshell, affirmative action has not been able to significantly increase the quantity as well as the quality of female legislators due to a number of internal and external factors. Confirming various scholars' arguments discussed in the previous section, political, cultural, social and economic factors have distorted the potential benefits of gender quota system.

Nevertheless, a relatively different story comes from women's existence in other government units. Different from local assemblies, gender-balanced has been relatively achieved particularly in the local government offices (Dinas-Dinas). In other words, numbers of male and female bureaucrats (civil servants) are relatively balanced. In City of Cirebon, the comparison between female and male bureaucrats is 48:52 per cent (BPS 2008). Such an achievement has been perceived by informants as relatively successful implementation of gendermainstreaming policy across local government units.

Indeed, the Government of City of Cirebon and District of Cirebon have conducted extensive and intensive gender mainstreaming socialization programs not only to a number of government units, but also certain segments in society such as teachers. Hence, these efforts have been claimed as the ultimate factor contributed to the substantial participation of women in various government units.

No less important factors is that there have been relatively insignificant resistance among the locals concerning women working as bureaucrats, compared to those of being politicians. In fact, Cirebonese women's enthusiasm is always high in every recruitment process signed by high numbers of women applicants. This implies that they gain fully support from their respective family. At the same time, it opposes the notion that Islam has been a significant barrier for women to be active outside their homes.

\section{CONCLUSION}

Women's equal participation and representation is a strategic basis for achieving gender equality. Nevertheless, as many other countries' experiences, the political playing field is uneven and hostile to women's political participation. The two case studies from City and District of Cirebon confirm that there are a number of political, cultural, social and economic obstacles to women's political participation.

Intended to remedy the gender gap, affirmative action policy in the form of gender quota has not been able to improve the quantity and quality of women political participation as well as representation. Besides facing obstacles during their candidacies, the challenges and difficulties continue after being elected. Simply put, their limited numbers, limited capacity, and limited experience in political field, have made them overpowered by their male counterparts. In addition, the existence of female representative so far has not been able to voice gender sensitive issues into various policies. In other words, their existence has not made any different in facilitating better consequences for Cirebonese women and children.

It has been reminded that limited number of women representatives in elected body would impoverish the development of democratic principles and sluggish economic development [10] he presence of adequate number of women in politics could strengthen the promotion of gender-sensitive issues into various strategic government policies. Hence, it is a must.

The experience of City and District of Cirebon reveals that affirmative action policy itself is not sufficient strategy for reducing gender-gap. It should be accompanied by other critical strategies, namely:

1. Improve and implement national legal system which fully support gender-equality;

2. Intensify political education for the society to develop and strengthen democratic culture and political maturity;

3. Demanding political parties to consistently and meaningfully adopt gender quota system together with proper political education and objective recruitment process for their cadres;

4. Intensive and sustainable female legislators' empowerment through various education and training to improve their skills and capacities as well as their responsiveness and sensitivity towards their constituents' needs;

5. Intensify civic education and media coverage on the importance of women political participation and gender equality.

\section{REFERENCES}

[1] Ballington, J, "Introduction" In Women's political participation: beyond numbers, J. Ballington, \& A. Karam, Stockholm: International IDEA, 2005, pp. 23-30.

[2] T., Bouta, G. Frerks, \& I. Bannon, Gender, conflict, and development. Washington, DC: The World Bank, 2005

[3] N.Burns, K. L, Schlozman, \& S.Verba, The private roots of public action: gender, equality, and political participation. Cambridge, MA: Harvard University Press, 2001.

[4] C.Bylesjo, \& J.Ballington, "Introduction", In Strengthening women's political participation in Indonesia, Jakarta: International IDEA, 2002, pp. 3-6.

[5] Soetjipto, A, "Increasing women;s political participation through constitutional and electoral reforms". In Conference Report: Strengthening Women's Political Participation in Indonesia, 2002, pp. 7 18.

[6] Budianta, M., "Decentralizing engagements: women and the democratization process in Indonesia". Signs: Journal of Women in Cultural and Society, vol. 31, no. 4, 2006, pp. 915-923.

[7] D. Dahlerup. Quotas - A Jump to Equality?, 2002, September 25, Retrieved Oktober 14, 2016, [Available from Legislationonline: http://www.legislationonline.org]. 
[8] L.Xu, Effects of female political participation on economic growth: evidence from Asian countries. 2015, June. Retrieved October 14, 2016 [Available

from http://lup.lub.lu.se/luur/download?func=downloadFile\&recordOId=7370 152\&fileOId=7370159]
[9] Halder, N. "Female representation in parliament: a case study from Bangladesh" In New Zealand Journal of Asian Studies, vol. 6, no. 1, 2004, pp. 27-63.

[10] Shvedova, N., "Obstacles to women's participation in parliament". In Women in parliament: beyond numbers, J. Ballington, \& A. Karam, Stockholm: International IDEA, 2005, pp. 33-50. 